\title{
Lithium-nickel cobalt oxides with spinel structure prepared at low temperature. XRD, XPS, and EIS measurements
}

\author{
E. Meza ${ }^{\mathrm{a}, 1}$, J. Ortiz ${ }^{\text {a }}$, D. Ruíz-León a , J.F. Marco ${ }^{\text {b }}$, J.L. Gautier ${ }^{\text {a,* }}$ \\ a Dpto. de Química de los Materiales, Facultad de Química y Biología, USACh Av. L.B.O'Higgins 3363, 9170022 Santiago, Chile \\ b Instituto de Química Física “Rocasolano”, CSIC; c/Serrano 119, 28006 Madrid, Spain
}

\section{A R T I C L E I N F O}

\section{Article history:}

Received 13 October 2011

Accepted 27 November 2011

Available online 9 December 2011

\section{Keywords:}

Mixed oxides

Lithium diffusion

Sol-gel

XPS

EIS

\begin{abstract}
A B S T R A C T
$\mathrm{Li}$, Co and $\mathrm{Ni}$ mixed oxides of composition $\mathrm{LiNi}_{\mathrm{x}} \mathrm{CO}_{2}-\mathrm{x} \mathrm{O}_{4}(\mathrm{x}=0.25,0.5,0.75$ and 1$)$ were prepared at $280^{\circ} \mathrm{C}$ by the Pechini sol-gel method. The Rietveld refinement of the X-ray diffraction data indicated that all the obtained compounds crystallize in the Fd3m space group characteristic of cubic spinel-related oxides. XPS studies on these oxides reveal the presence of $\mathrm{Ni}^{2+}, \mathrm{Ni}^{3+}, \mathrm{Co}^{3+}$ and $\mathrm{CO}^{4+}$ ions at the surface. The diffusion coefficients of the $\mathrm{Li}^{+}$ ion in the oxide lattice, determined by EIS measurements, are larger $\left(10^{-13} \mathrm{~cm}^{2} \mathrm{~s}^{-1} \leq \mathrm{D} \leq 10^{-10} \mathrm{~cm}^{2} \mathrm{~s}^{-1}\right)$ than that shown by the non-substituted cobalt-lithium oxide, $\mathrm{LiCo}_{2} \mathrm{O}_{4}\left(\mathrm{D}=10^{-16} \mathrm{~cm}^{2} \mathrm{~s}^{-1}\right)$ and present similar values to those of layered oxides of related composition.
\end{abstract}

(C) 2011 Elsevier B.V. All rights reserved.

\section{Introduction}

The demands for advanced energy storage devices, motivated by a variety of different needs, have increased significantly in recent years. Rechargeable lithium-ion battery (LiB) has become the best device for electric and hybrid electric vehicles [1]. Layered lithium oxides $\mathrm{LiMO}_{2}$ $(\mathrm{M}=\mathrm{Co}, \mathrm{Ni}, \mathrm{Mn})$ and their doping metal variants are well-established commercial $\mathrm{LiB}$ cathode materials. Particularly, $\mathrm{LiCoO}_{2}$ commercialized from 1991, has been the more successful oxide. However, the cobalt is ex-


cathode material, where $\mathrm{Co}$ is replaced by $\mathrm{Ni}$, has been intensively studied [2-4]. The structure of this oxide system (S.G. R3m) is formed by bidimensional layers of $\mathrm{CoO}_{2}$ units [5]. On the other hand, it is well known that lithium cobaltite, $\mathrm{LiCO}_{2} \mathrm{O}_{4}$, prepared at $300-400{ }^{\circ} \mathrm{C}$, crystallizes in the spinel structure (S.G. Fd3m) containing vacant octahedral sites susceptible to the reversible insertion of Li-ions [6-8]. We have reported in a previous work good Li-ion insertion-extraction properties on lithium cobaltite $\mathrm{LiCo}_{2} \mathrm{O}_{4}$ synthesized at $400{ }^{\circ} \mathrm{C}$ [9].

In this work, we have attempted the synthesis at low temperature $\left(280{ }^{\circ} \mathrm{C}\right)$ by a sol-gel method [10] of the nickel-substituted lithium cobaltite $\mathrm{LiNi}_{\mathrm{x}} \mathrm{CO}_{2}{ }_{-} \mathrm{O}_{4}$, having a spinel-related structure. The 3D lattice parameters were refined by the Rietveld method [11,12], and the surface composition was studied by XPS. Electrochemical impedance

\footnotetext{
* Corresponding author. Tel.: +56 27181163.

E-mail address: juan.gautier@usach.cl (J.L. Gautier).

1 Permanent address: Dpto. Metalurgia, unap, A.Prat 2120, Iquique, Chile.
}

spectroscopy (EIS) technique [13] was used to evaluate the $\mathrm{Li}^{+}$ion diffusion coefficient in the oxides.

\section{Experimental}

Oxides of the $\mathrm{LiNi}_{\mathrm{x}} \mathrm{CO}_{2}{ }_{\mathrm{x}} \mathrm{O}_{4}$ series $(\mathrm{x}=0.25,0.5,0.75$ and 1$)$ were synthesized using the Pechini method [10]. This is a sol-gel procedure

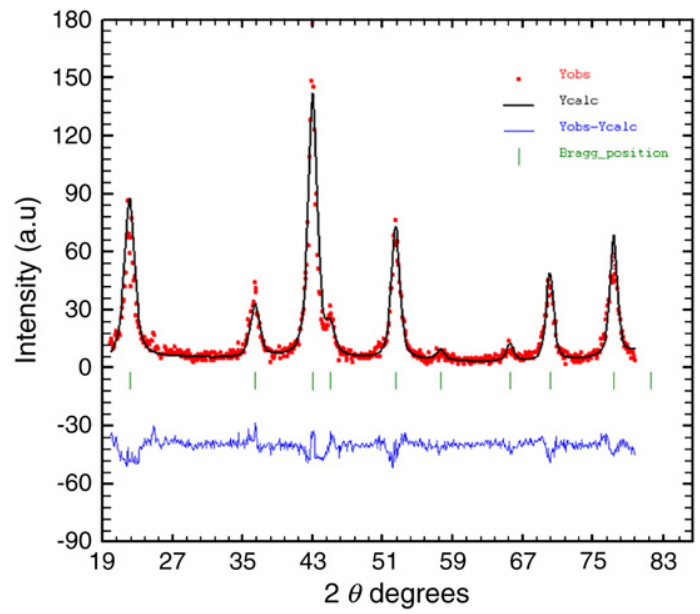

Fig. 1. Observed and calculated XRD profiles of $\mathrm{LiNi}_{0.5} \mathrm{Co}_{1.25} \mathrm{O}_{4}$. S.G. $\mathrm{Fd} 3 \mathrm{~m}$. $\mathrm{R}_{\mathrm{wp}}=12.7 \%$, $R_{\exp }=11.4 \%, \chi^{2}=3.35 \%$ 
Table 1

Cation distributions of the $\mathrm{LiNi}_{\mathrm{x}} \mathrm{CO}_{2}-\mathrm{x}_{4}$ oxides. Experimental and calculated cell parameter. The brackets indicate the octahedral sites.

\begin{tabular}{llll}
\hline $\mathrm{x}$ & Cationic distribution & $\mathrm{a}_{\exp } / \mathrm{nm}$ & $\mathrm{a}_{\text {calc. }} / \mathrm{nm}$ \\
\hline 0.25 & $\mathrm{Li}^{+}\left[\mathrm{Ni}^{3+}{ }_{0.25} \mathrm{Co}^{3+}{ }_{0.75} \mathrm{Co}^{4+}\right]$ & 0.803 & 0.801 \\
0.5 & $\mathrm{Li}^{+}\left[\mathrm{NI}^{3+}{ }_{0.5} \mathrm{Co}^{4+}{ }_{1.5}\right]$ & 0.807 & 0.804 \\
0.75 & $\mathrm{Li}^{+}\left[\mathrm{Ni}^{3+}{ }_{0.75} \mathrm{Co}^{3+}{ }_{0.25} \mathrm{Co}^{4+}\right]$ & 0.809 & 0.806 \\
1 & $\mathrm{Li}^{+}\left[\mathrm{Ni}^{3+}{ }^{\left.+{ }_{0}{ }^{4+}\right]}\right.$ & 0.811 & 0.808 \\
\hline
\end{tabular}

that involves the dissolution of the nitrates (or carbonates) of the respective metals in a $1: 4 \mathrm{v} / \mathrm{v}$ mixture of $1 \mathrm{~mol} \mathrm{dm}^{-3}$ of citric acid and etilenglicol. Upon heating, esterification takes place $\left(120^{\circ} \mathrm{C}\right)$ and, after drying in vacuum at $180^{\circ} \mathrm{C}$, polymerization occurs. Increasing gradually the temperature at $1.5^{\circ} \mathrm{C} \mathrm{min}^{-1}$ from $180^{\circ} \mathrm{C}$ to $280^{\circ} \mathrm{C}$ in oxygen atmosphere, a polycrystalline and ultra fine powder is obtained after $48 \mathrm{~h}$. The nominal composition was corroborated by chemical analysis.

The XRD data were recorded with a Siemens 5000 diffractometer using $\mathrm{CoK} \alpha$ radiation $(0.178897 \mathrm{~nm})$ and a scanning rate of $4^{\circ} \mathrm{min}^{-1}$. The XPS spectra were recorded under a vacuum better than $1 \times 10^{-8}$ mbar, using $\mathrm{Al} \mathrm{K \alpha}$ radiation $(1486.6 \mathrm{eV})$ and a constant pass energy of $50 \mathrm{eV}$. All binding energies $(\mathrm{BE} \pm 0.2 \mathrm{eV})$ were referred to the $\mathrm{C} 1 \mathrm{~s}$ signal $(284.6 \mathrm{eV})$.

The studies of EIS were performed in a Swagelok ${ }^{\mathrm{TM}}$ type cell [14] using an oxide pellet ( $1 \mathrm{~mm}$ thickness) containing acetylene black and Teflon in a 90:5:5 mass ratio. As anode and reference electrode a metallic Li-wire was used. The electrolyte was a $1 \mathrm{M} \mathrm{LiBF}_{4}$ solution in EC:DMC $1: 1(w / w)$. All components of the electrochemical cell were assembled under Ar-atmosphere. The impedance measurements were obtained using a 301 Voltalab PGZ Radiometer. An alternating perturbation of
$200 \mathrm{mV}$ and a frequency $(\omega)$ between $100 \mathrm{KHz}$ and $1 \mathrm{MHz}$ were employed.

\section{Results and discussion}

The XRD data refined by Rietveld method corroborate that all oxides crystallize in a cubic spinel structure (S.G. Fd3m). As an example, the observed and calculated diffraction patterns for $\mathrm{LiNi}_{0.5} \mathrm{Co}_{1.5} \mathrm{O}_{4}$, are shown in Fig. 1.

In order to obtain the probable cationic distribution for each composition, crystallographic distribution were proposed, starting from the XRD measurements, assuming that ions $\mathrm{Li}^{+}, \mathrm{Ni}^{2+}, \mathrm{Ni}^{3+}, \mathrm{Co}^{3+}, \mathrm{CO}^{4+}$ can be present according to their energetic preference to occupy tetrahedral (4) and octahedral (6) sites [15]. We have used the relationship of Poix [16] that allows estimating the $a$ cell parameter of oxides on the basis of the ion-oxygen length as a function of oxygen coordination: $a=2.0995 \mathrm{~A}+\left(5.8182 \mathrm{~B}^{2}-1.4107 \mathrm{~A}^{2}\right)^{1 / 2}$ where $\mathrm{A}=\Sigma \mathrm{x}_{\mathrm{i}}\left(\mathrm{M}_{\mathrm{i}}-\mathrm{O}\right)_{4}$ and $2 \mathrm{~B}=\Sigma \mathrm{y}_{\mathrm{i}}\left(\mathrm{M}_{\mathrm{i}}-\mathrm{O}\right)_{6}, \mathrm{x}_{\mathrm{i}}$ and $\mathrm{y}_{\mathrm{i}}$ are the stoichiometric coefficients and $\mathrm{M}_{\mathrm{i}}-\mathrm{O}$ the cation-oxygen distances. The following values were used [17]: $\quad \mathrm{Ni}^{2+}{ }_{-} \mathrm{O}_{4}=0.209 ; \quad \mathrm{Li}^{+}{ }_{-} \mathrm{O}_{6}=0.204 ; \quad \mathrm{Co}^{3+}{ }_{-} \mathrm{O}_{6}=0.189 ; \quad \mathrm{Co}^{4+}{ }_{-}$ $\mathrm{O}_{6}=0.178 ; \mathrm{Ni}^{3+}-\mathrm{O}_{6}=0.196 \mathrm{~nm}$.

The calculated value of $a$ is compared with the experimental one to evaluate the validity of the cationic distribution. Table 1 shows the proposed distributions. The large concentration of $\mathrm{Co}^{4+}$ ions for $\mathrm{x}=0.5$ can be accepted considering the low molar Curie constant $\left(0.2 \mathrm{~cm}^{3} \mathrm{~K} \mathrm{~mol}^{-1}\right)$ obtained from the magnetic measurements (Faraday method) at $300 \mathrm{~K}[18]$.

The XPS results suggest that $\mathrm{Ni}^{2+}, \mathrm{Ni}^{3+}, \mathrm{Co}^{3+}$ and $\mathrm{Co}^{4+}$ are present in the surface of the oxides. In the case of Co (Fig. 2A), the spectra were fitted considering two-spin orbit doublets (Do) and three satellite (S) peaks. We have adopted the criterion of fixing equal widths for the
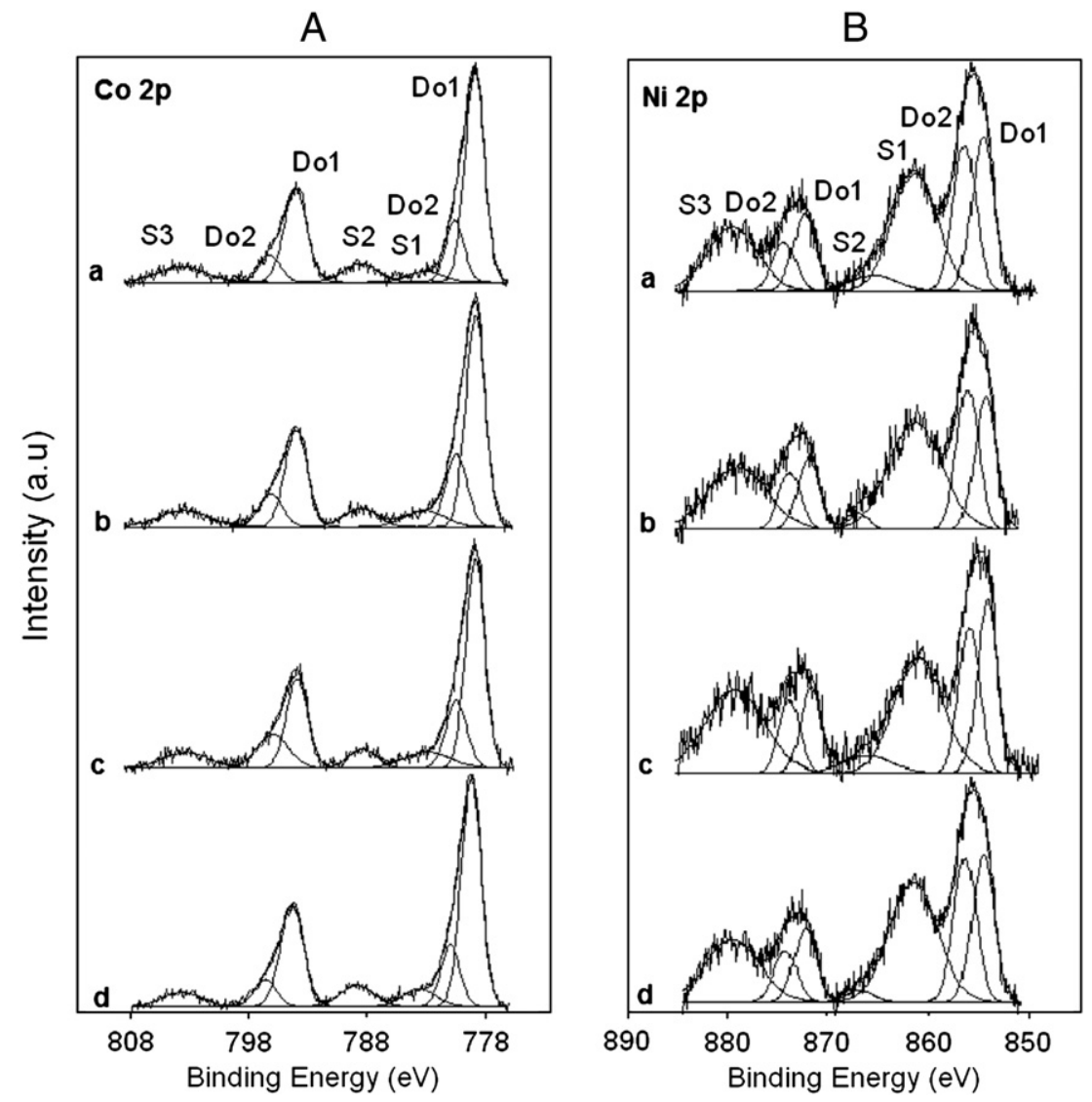

Fig. 2. Co 2p (A) and Ni 2p (B) XP spectra recorded from $\mathrm{LiNi}_{\mathrm{x}} \mathrm{Co}_{2-\mathrm{x}} \mathrm{O}_{4}$ samples: a) $\mathrm{x}=0.25$, b) $\left.\mathrm{x}=0.5, \mathrm{c}\right) \mathrm{x}=0.75$, $\left.d\right) \mathrm{x}=1$. 
Table 2

Results obtained from the fit of A) Co 2p XP spectra, B) Ni 2p XP spectra.

\begin{tabular}{|c|c|c|c|c|c|c|c|}
\hline \multicolumn{8}{|l|}{ A } \\
\hline & \multicolumn{2}{|l|}{ Do 1} & \multicolumn{2}{|l|}{ Do 2} & \multirow[t]{2}{*}{ Sat. 1} & \multirow[t]{2}{*}{ Sat. 2} & \multirow[t]{2}{*}{ Sat. 3} \\
\hline & Co $2 \mathrm{p}_{3 / 2}$ & Co $2 \mathrm{p}_{1 / 2}$ & Co $2 \mathrm{p}_{3 / 2}$ & Co $2 \mathrm{p}_{1 / 2}$ & & & \\
\hline $\mathrm{BE}(\mathrm{eV})$ & $778.8 \pm 0.2$ & $793.9 \pm 0.2$ & $780.5 \pm 0.2$ & $796.0 \pm 0.2$ & $783.1 \pm 0.2$ & $788.5 \pm 0.2$ & $803.4 \pm 0.2$ \\
\hline FWHM (eV) & $2.0 \pm 0.1$ & $2.2 \pm 0.1$ & $2.0 \pm 0.2$ & $2.5 \pm 0.3$ & $4.1 \pm 0.4$ & $3.3 \pm 0.3$ & $5.0 \pm 0.2$ \\
\hline Assignment & $\mathrm{Co}^{3+}$ & & $\mathrm{Co}^{4+}$ & & $\mathrm{Co}^{4+}$ & $\mathrm{Co}^{3+}$ & $\mathrm{Co}^{3+}+\mathrm{Co}^{4+}$ \\
\hline \multicolumn{8}{|l|}{$B$} \\
\hline & \multicolumn{2}{|l|}{ Do 1} & \multicolumn{2}{|l|}{ Do 2} & \multirow[t]{2}{*}{ Sat. 1} & \multirow[t]{2}{*}{ Sat. 2} & \multirow[t]{2}{*}{ Sat. 3} \\
\hline & $\mathrm{Ni} 2 \mathrm{p}_{3 / 2}$ & $\mathrm{Ni} 2 \mathrm{p}_{1 / 2}$ & $\mathrm{Ni} 2 \mathrm{p}_{3 / 2}$ & Ni $2 p_{1 / 2}$ & & & \\
\hline $\mathrm{BE}(\mathrm{eV})$ & $852.4 \pm 0.2$ & $870.1 \pm 0.2$ & $854.5 \pm 0.2$ & $871.6 \pm 0.2$ & $859.5 \pm 0.2$ & $863.3 \pm 0.7$ & $877.3 \pm 0.1$ \\
\hline FWHM eV) & $1.9 \pm 0.2$ & $1.9 \pm 0.2$ & $3.1 \pm 0.2$ & $3.4 \pm 0.2$ & $4.9 \pm 0.4$ & $5.0 \pm 0.4$ & $6.5 \pm 0.1$ \\
\hline Assignment & $\mathrm{Ni}^{2+}$ & & $\mathrm{Ni}^{3+}$ & & & & \\
\hline
\end{tabular}

two main Co $2 \mathrm{p}_{3 / 2}$ lines of the two spin-orbit doublets. The BE's and the line widths obtained are given in Table 2. The most intense doublet (Do1) and the shake up satellite appearing at $788.5 \mathrm{eV}$ (S2) can be assigned unequivocally to $\mathrm{Co}^{3+}[19]$. In a recent XPS paper, Dupin et al. [20] have reported a binding energy for $\mathrm{Co}^{4+}$ similar to that shown in the present study. Therefore the doublet (Do2) is associated to $\mathrm{Co}^{4+}$. The Ni $2 \mathrm{p}_{3 / 2}$ spectra recorded from these compounds also show a complex structure (Fig. 2B) with two different spin-orbit doublets and three satellite peaks. In this case, it was not possible to fix the line width of the two main $\mathrm{Ni} 2 \mathrm{p}_{3 / 2}$ lines to be equal, since this constraint clearly resulted in a very poor fit. A better fit was obtained when the doublet appearing at lower binding energy (Do1) was fitted with a narrower line width than that of the doublet appearing at higher binding energy (Do2). The results are given in Fig. 2B and Table 2. The small intensity doublet is associated to a $\mathrm{Ni}^{2+}$ component while the most intense doublet is ascribed to $\mathrm{a} \mathrm{Ni}^{3+}$ component.

The surface composition does not fit completely the bulk cation distribution determined by XRD. This is not totally surprising since, in fine grained materials like these, the solubility of the different cations can depend on grain size leading to different composition at the surfaces or the interfaces at the grain boundaries between the different crystallites [21].

A way to estimate how easy it is to move the lithium ions inside the oxide network is to measure the diffusion coefficient, D. This parameter was determined using the EIS technique. Fig. 3 shows the Nyquist diagrams for the series of the studied oxides. As it is well-known, the

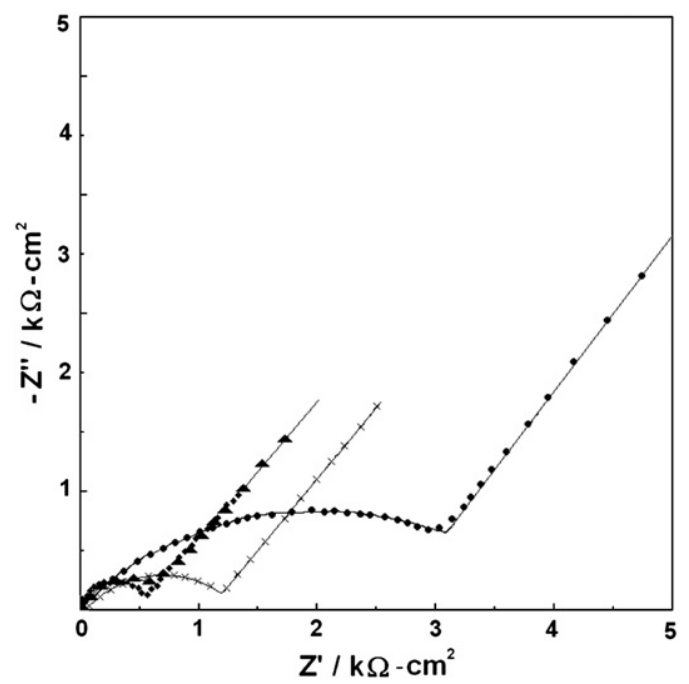

Fig. 3. Nyquist diagrams of $\mathrm{LiNi}_{\mathrm{x}} \mathrm{Co}_{2}{ }_{-\mathrm{x}} \mathrm{O}_{4}$ oxides. $\bullet: \mathrm{x}=0.25, \bullet: \mathrm{x}=0.5, \mathbf{\Delta}: \mathrm{x}=0.75$, : $\mathrm{x}=1$. part corresponding to the charge transfer is located in the semicircles of the diagrams while the diffusional part is located in the linear zone of the diagram corresponding to the low frequency region. In this zone the Warburg impedance, $Z_{W}$, which is proportional to $\omega^{-1 / 2}$, can be determined. From the slope, $\sigma$, of the straight lines of the Warburg graphs ( $Z_{W}$ versus $\omega^{-1 / 2}$, not shown), it was possible to obtain $D_{\mathrm{Li}}+$ for each composition by means of the expression: $\sigma=\mathrm{RT} /(\mathrm{nF})^{2}$ $\left[\sqrt{ } 2 / \mathrm{D}^{1 / 2} \mathrm{C}^{\mathrm{o}}\right]$, where $\mathrm{RT} /(\mathrm{nF})=25.69310^{-3}(\mathrm{~A} \Omega), \quad \mathrm{F}=96485[\mathrm{C} / \mathrm{mol}]$, $\mathrm{C}^{\mathrm{o}}=1 \mathrm{~mol} / \mathrm{dm}^{-3}$ (electrolyte concentration). In the case of the $\mathrm{x}=0.5$ composition, the charge transfer region is remarkably more important than the diffusional zone. It can be observed that this composition contains the largest $\mathrm{Co}^{4+}$ cation concentration in octahedral sites. According to this, a greater electrical repulsion on the $\mathrm{Li}^{+}$ions would diminish their diffusion coefficient. The $\mathrm{D}_{\mathrm{Li}}^{+}$values obtained for the several $\mathrm{x}$-compositions, are: $2.3 \times 10^{-10}(\mathrm{x}=0.25) ; 2.1 \times 10^{-13}$ $(\mathrm{x}=0.5) ; 1.4 \times 10^{-13}(\mathrm{x}=0.75)$ and $2.2 \times 10^{-13}(\mathrm{x}=1)\left(\mathrm{cm}^{2} / \mathrm{s}\right)$.

\section{Conclusions}

This work shows that is possible to prepare $\mathrm{LiNi}_{\mathrm{x}} \mathrm{CO}_{2}{ }_{-\mathrm{x}} \mathrm{O}_{4}(\mathrm{x}=0.25$, $0.5,0.75$ and 1 ) at $280^{\circ} \mathrm{C}$ crystallizing in a spinel S.G. Fd3m structure. XRD and XPS studies indicate the presence of $\mathrm{Li}^{+}, \mathrm{Ni}^{3+}, \mathrm{Co}^{3+}, \mathrm{Co}^{4+}$ ions. These ions particularly $\mathrm{Co}^{4+}$ ions should be responsible for the wide charge region observed on EIS measurements. $\mathrm{Li}^{+}$diffusion coefficients as a function of nickel composition are in the order of $10^{-13} \mathrm{~cm}^{2} \mathrm{~s}^{-1}$ that can be also attributed to $\mathrm{Co}^{4+}$ concentration. Dvalues are similar in magnitude to those presented in the literature of layered oxides of related composition, $\mathrm{Li}_{\mathrm{x}} \mathrm{Ni}_{0.8} \mathrm{Co}_{0.2} \mathrm{O}_{2}$ [22] and $\mathrm{Li}_{\mathrm{X}} \mathrm{Ni}_{0.8}$ $\mathrm{Co}_{0.2} \mathrm{O}_{2}[23]$.

\section{Acknowledgments}

The authors acknowledge financial support from CONICYT (Fondecyt No. 1110755), MICINN (MAT2009-14578-CO3-01) and bilateral cooperation programme CSIC/USACH.

\section{References}

[1] Horiba T, Matsumura J. J Power Sources 2001;97-98:719-21.

[2] Delmas C, Saadoune I. Solid State Ionics 1992:53-56:370-5.

[3] Zhecheva E, Stoyanova R. Solid State Ionics 1993;66:143-9.

[4] Saadoune I, Delmas C. J Mater Chem 1996;6:193-9.

[5] Whittingham MS. Chem Rev 2004;104:4271-302.

[6] Manthiram A, Choi J, Choi W. Solid State Ionics 2006;177:2629-34.

[7] Choi S, Manthiram A. J Electrochem Soc 2002;149:A162-6.

[8] Gummow RJ, Liles DC, Thackeray MM. Mater Res Bull 1993;28:235-46.

[9] Meza E, Alburquenque D, Ortiz J, Gautier JL. J Chil Chem Soc 2008;53:1494-7.

[10] Pechini M, 1967; US: Pat. 3.330.697 8.

[11] Rodríguez-Carvajal J. An introduction to fullproof 2000 program; 2001. version July.

[12] Young RA. The rietveld method. Int. union crystallography. Oxford Science Pub.; 1995 
[13] Bard AJ, Faulkner L. Electrochemical methods, fundamentals and applications. New York: John Wiley and Sons; 1980.

[14] Guyomard D, Tarascon JM. J Electrochem Soc 1992;139:937-48.

[15] Orgel LE. An introduction to transition metal chemistry: ligand field theory. London: Methuen; 1960

[16] Poix P. Bull Soc Chim 1965;1:1085-7.

[17] Shannon RD. Acta Cryst 1976;B25:751-67.

[18] Meza E, private communication.
[19] Nagaura T, Tazawa K. Prog Batteries Solar Cells 1990;9:20-5.

[20] Dupin JC, Gonbeau D, Benglilou-Moudden H, Vinatier Ph, Levasseur A. Thin Solid Films 2001;384:23-32.

[21] Straumal BB, Mazilkin AA, Protasova SG, Myatiev AA, Straumal PB, Baretzky B. Acta Mater 2008;56:6246-56.

[22] Idemoto I, Takanashi Y, Kitamura N. J Power Sources 2009;189:269-78.

[23] Abraham DP, Kawashi S, Dees DW. Electrochim Acta 2008;53:2121-9. 